\title{
C.G. PAINE AND THE EARLIEST SURVIVING CLINICAL RECORDS OF PENICILLIN THERAPY
}

\author{
by
}

\author{
MILTON WAINWRIGHT* AND HAROLD T. SWAN ${ }^{+}$
}

\section{INTRODUCTION}

In August 1940, the Oxford team, which included Chain and Florey, made a preliminary announcement in the Lancet $^{1}$ of their successful development of penicillin into a partially purified preparation of reliable activity, which could be given by injection. They gave case histories to illustrate their success in a full article in the following year. ${ }^{2}$ Eleven years before these important announcements, in 1929, Fleming ${ }^{3}$ had published details of his fundamental discovery of penicillin as an antibacterial agent, but in the meantime the therapeutic potential of penicillin had not been much pursued, by himself or by anyone else. But, as this paper shows, penicillin was used therapeutically and successfully, as a local application, as early as 1930. Three claims that penicillin had been used effectively on patients around that time have arisen from work by Fleming himself, C.G. Paine, and A. Dickson Wright, but until now no claim has been substantiated by documented clinical notes. When the journalist David Masters interviewed Professor Florey with a view to writing a book on penicillin, ${ }^{4}$ Florey recalled that some early work on penicillin had been undertaken in Sheffield by a young hospital pathologist, Dr C.G. Paine, whose own words were later quoted by Florey in a book on antibiotics written by the Oxford team. ${ }^{5}$ Although he later rued the fact, Paine never submitted for publication the work he had done on penicillin in 1930-31, but his significant part in the penicillin story is now being related in greater detail than hitherto, together with his own recent comments on the subject.

\section{BIOGRAPHICAL NOTES}

Cecil George Paine (fig.1) was born in London in 1905, and attended the Central Foundation School and later Christ's Hospital, where he stayed from the age of

*Milton Wainwright, BSc, PhD, Lecturer in Microbiology, Department of Microbiology, University of Sheffield, Sheffield S10 2TN.

tHarold T. Swan, MD, FRCP, FRCPath, Honorary Lecturer, Sub-Department of Medical History, c/o Haematology Department, Royal Hallamshire Hospital, Sheffield S10 2JF.

${ }^{1}$ E. Chain, H. W. Florey, A. D. Gardner, N. G. Heatley, M. A. Jennings, J. Orr-Ewing, and A. G. Sanders, 'Penicillin as a chemotherapeutic agent', Lancet, 1940, ii: 226-228.

${ }^{2}$ E. P. Abraham, E. Chain, C. M. Fletcher, H. W. Florey, A. D. Gardner, N. G. Heatley, and M. A. Jennings, 'Further observations on penicillin', ibid., 1941, ii: 177-188.

${ }^{3} \mathrm{~A}$. Fleming, 'On the antibacterial action of cultures of a Penicillium with special reference to their use in the isolation of B. influenzae', Br. J. exper. Path., 1929, 10: 226-236.

${ }^{4} D$. Masters, Miracle drug, London, Eyre \& Spottiswoode, 1946.

${ }^{5}$ H. W. Florey, E. Chain, N. G. Heatley, M. A. Jennings, A. G. Sanders, E. P. Abraham, and M. E. Florey, Antibiotics, vol. 2, Oxford University Press, 1949. 


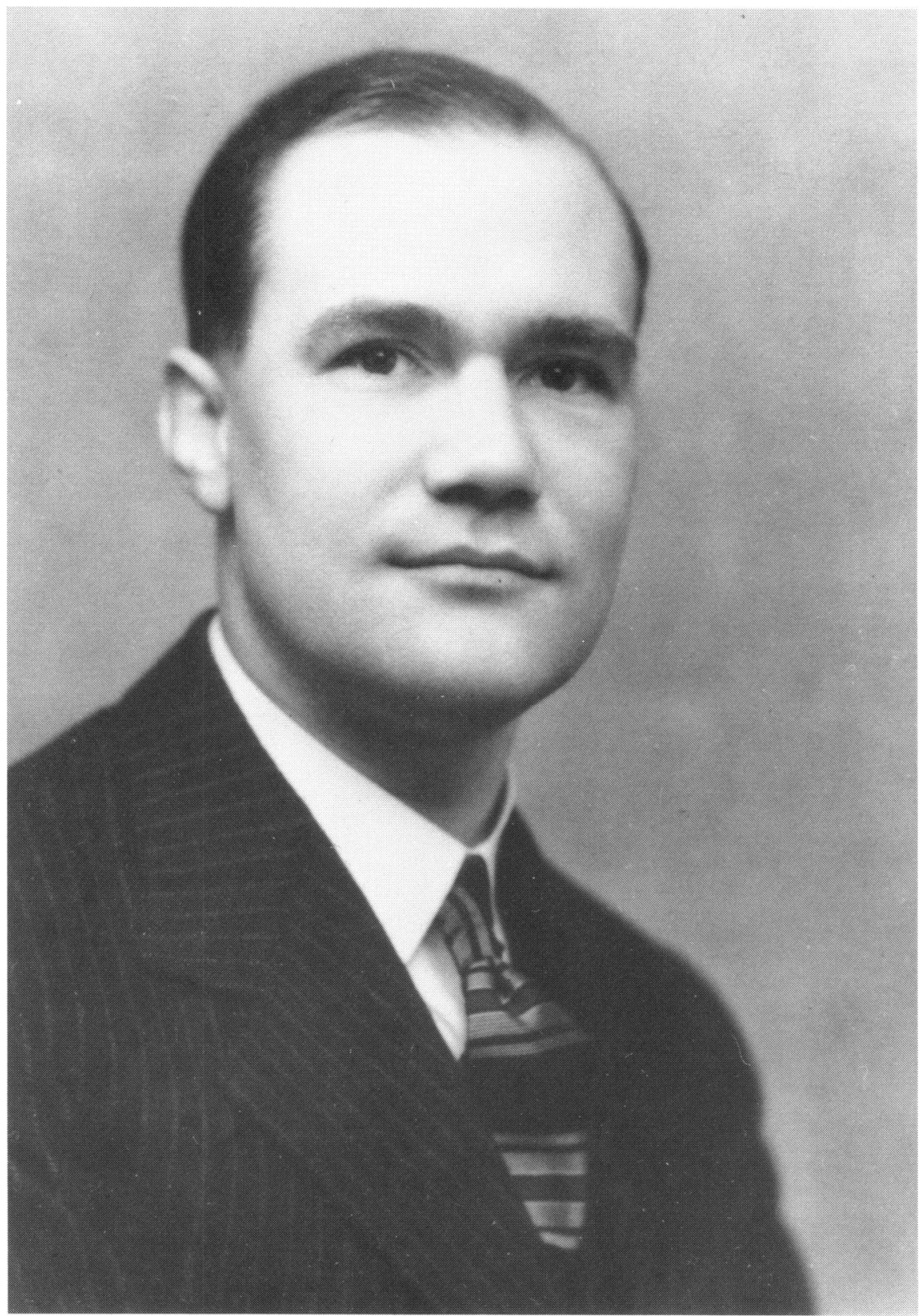

Figure 1. C. G. Paine in the mid-1930s. Source: C. G. Paine. 


\section{G. Paine and penicillin therapy}

eleven until he was nineteen years old. Although there had been no medical tradition in the family, he proceeded to St Mary's Hospital Medical School in London, where Fleming was lecturer in bacteriology. He passed the Conjoint qualifying examination in 1928 and MB BS of London University in the following year, and moved to Sheffield to take up his first appointment on 1 January 1929. He remained in Sheffield for the rest of his career. He acquired his MD in 1933, a Fellowship of the Royal College of Obstetricians and Gynaecologists in 1961, and a Founder Fellowship of the Royal College of Pathologists in 1963.

In the minutes of the Weekly Board of the Sheffield Royal Infirmary for 12 December 1928 there occurs the first of three entries in which Paine's coming appointment is variously described as that of Clinical Pathologist or Assistant Pathologist to the Infirmary and additionally as Demonstrator of Pathology in the University. ${ }^{6,7}$ The annual reports of the hospital during that period give no indication that Paine was on the staff, despite the inclusion of the names, amongst others, of the honorary pathologist and of house staff. The reason for this omission is not clear. Paine was appointed lecturer in bacteriology in 1932, but his name does not appear in the history of Sheffield University. ${ }^{8}$ He remained at the Royal Infirmary for just over two years, and it was towards the end of 1930 and during the subsequent three months of 1931 that he developed a practical interest in penicillin, which he had first heard of as a student. It is this short six-month period of his career which is particularly relevant to this paper. Dr Paine described his work at the time in a recent conversation with MW at Ottery St Mary, Devon:

I wrote to Fleming [one of Dr Paine's former lecturers] to get some cultures of his Penicillium from him and this I did, and made some brews with the usual meat broth. I did my own titrations against a Staphylococcus. I used this as a test organism although it wasn't supplied by Fleming -it wasn't Staph. aureus, that I am quite sure about. I think that it was Staph. albus. I used it because I didn't want a particularly virulent organism for my test control. I had been working at that time upon the normal bactericidal power of the blood on Staph. aureus derived from sycosis of the beard as well as the ordinary skin variants - there was a difference but it wasn't particularly interesting. I had known about penicillin since 1928, and I had of course read the 1929 paper. I was friendly with one of the eye men so I asked if he'd like to try out its effects and this we did. I also tried the filtrate on sycosis barbae. I soaked pads in broth and applied it to the sides of the face. There were a lot of these infections about at the time and the dermatologist used to send these patients over to me to culture the staph. from them. I went to him and suggested that we try penicillin. The attempts to use penicillin against these infections came to nothing. I suppose that they were resistant strains, or that I was dealing with inadequate concentrations of penicillin, or too much meat broth. Next we tried it on those babies with gonorrhoeal infections and it worked like a charm! Then we had a man in from one of the mines locally and he'd got a bad laceration on his cornea. We took a culture from his cornea and grew up the organism that was absolutely dreaded in the eye-Pneumococcus. We tried penicillin and it cleared up the infection like nobody's business, and they were able to deal with him and he made a good recovery.

This was essentially the same description as Paine gave to Masters for inclusion in his book Miracle drug in $1946 ;{ }^{9}$ it also occurs in the section devoted to the history of penicillin in the second volume of the book Antibiotics, written by the Oxford group led by Florey. ${ }^{10}$ The dermatologist referred to was Dr A. Rupert Hallam. The "eye

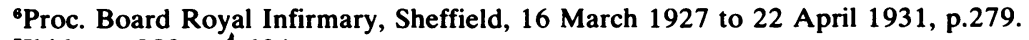

'Ibid., pp.282 and 604.

A. W. Chapman, The story of a modern university, Oxford University Press, 1950.

${ }^{9}$ Masters, op. cit., note 4 above, pp.57-60.

${ }^{10}$ Florey et al., op. cit., note 5 above, p.634. 


\section{Wainwright and H. T. Swan}

man" was Mr A.B. Nutt, who was assistant ophthalmic surgeon to the Royal Infirmary at that time. During the period under discussion, Paine appears to have been involved in the treatment of eight patients with penicillin. He and Dr Hallam treated three cases of sycosis barbae without any success. He also treated five eye infections, where the therapy was successful in four.

Most of the techniques used in modern microbiology were unknown at that time. The pathology laboratory at the Infirmary, for example, had no $25^{\circ} \mathrm{C}$ incubator in 1929 , and even blood agar, a routine bacteriological medium, was not used there until Paine arrived. He grew Penicillium notatum on meat broth essentially as Fleming had done. The cultures were grown without shaking, presumably at room temperature since a number of workers have shown that this fungus would not have been capable of growing at $37^{\circ} \mathrm{C}$, which was the incubation temperature favoured by bacteriologists. Every twenty-four hours, some broth was filtered and titrated against Staph. albus by a tube dilution method. Masters implies that Paine used a plate-assay method, but Dr Paine is certain that he used a liquid broth assay of his own, comparable to what was used originally by Fleming. ${ }^{11}$ Liquid broth assays were later shown to be unreliable due to uncontrollable daily fluctuations. ${ }^{12}$ Paine, like Fleming, never used a synthetic medium such as Czapek-Dox to culture Penicillium, a fact which reflects his exclusively bacteriological training. With wry humour, he commented that "at that time bacteriologists didn't even believe that mycologists existed", a view emphasized by the fact that Paine, while a student at St Mary's, was unaware of the presence of the mycologist C.J. La Touche.

Despite the interest in penicillin which he had developed during his last few months at the Royal Infirmary, Paine moved on to pursue his career in another direction. He had offered his resignation to the board in December 1930, but chose to work three months' notice rather than the contractual one month. On leaving the Infirmary at the end of March 1931, he spent April at the recently opened laboratories at Queen Charlotte's Hospital in London, gaining experience of puerperal fever with the help of Leonard Colebrook and Ronald Hare, and it was to the study of puerperal fever that Cecil Paine devoted most of his subsequent research.

When he returned to Sheffield, Paine went directly to his new post as bacteriologist at the Firth Auxiliary Hospital, later known as the Norton Annexe of the Jessop Hospital for Women, which was situated on the outskirts of the city at some distance from the Infirmary. The annexe received cases of puerperal sepsis and other disorders, to keep them isolated from the main hospital. Paine's active work on penicillin was terminated by this change of appointment. Recently, during a search for old case records which might refer to penicillin, it seemed reasonable to consider the period immediately before the end of March 1931. Dr Paine himself was unaware of there being any surviving records of his clinical experiments with penicillin, nor had he retained any laboratory records from that period.

${ }^{11}$ Fleming, op. cit., note 3 above.

12J. W. Foster and H. B. Woodruff, 'Microbiological aspects of penicillin', J. Bact., 1943, 46: 187-202. 


\section{G. Paine and penicillin therapy}

CASE REPORTS AND POINTS ARISING

A search was accordingly made (HTS) in the surviving Royal Infirmary ward journals of the late Mr A.B. Nutt, with whom Paine claimed to have achieved clinical successes. Mr Nutt's journals for 1930 still exist but not those for the subsequent year. Two relevant case histories were found. They are illustrated as figs. 2 and 3 , and are likely to be two of the five ophthalmic cases recollected by Paine and referred to by Florey in Antibiotics in $1949 .{ }^{5}$

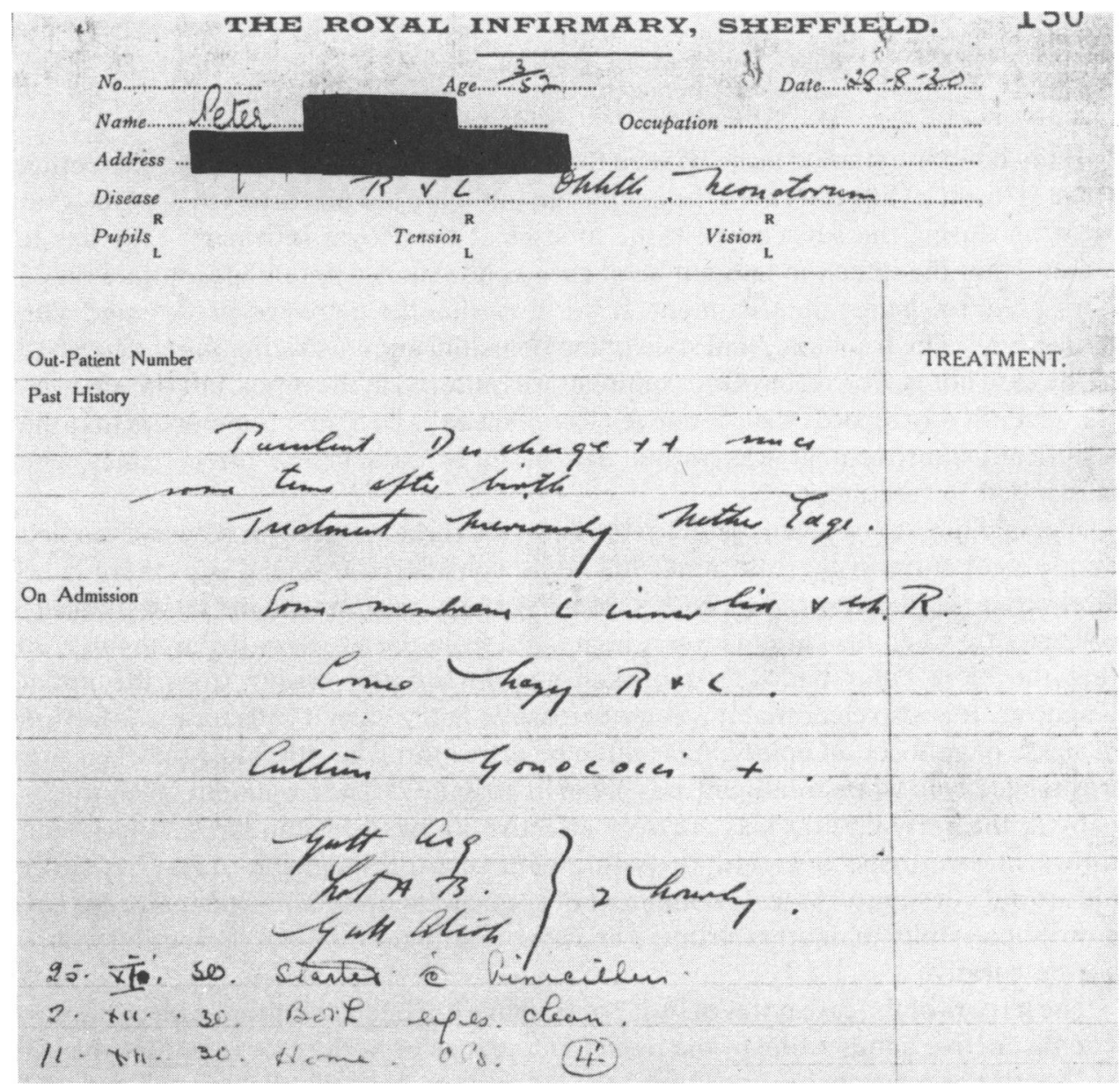

Figure 2. Case notes of 1930 recording penicillin therapy. Source: Sheffield Royal Infirmary case records, South Yorkshire County Records Office, Sheffield.

The first case (fig.2) concerns a three-week-old male baby, Peter, who was admitted to Mr Nutt's female ward on 28 August 1930. This baby is recorded as suffering from bilateral ophthalmia neonatorum of gonococcal origin with a copious discharge from the eyes "since some time after birth". The following is a transcription of the notes under the admission date of 28 August 1930. 


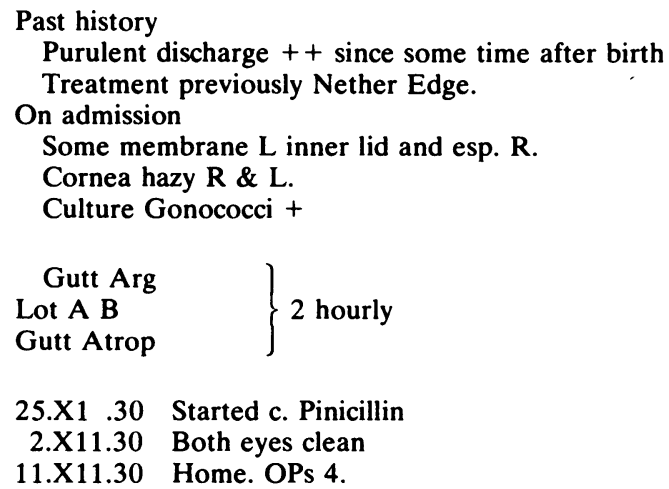

If the notes are studied it can be seen that the initial treatment of the eyes at Nether Edge (Hospital) had not cured the condition, but there are no entries to explain what went on during the subsequent three months at the Royal Infirmary. One has to assume that the infection had not been cured and that it was felt appropriate on 25 November to change the treatment. It was then that the baby was first treated with "pinicillin". The frequency and style of the penicillin administration is not described in the case notes. For six days, no comment was entered in the notes, but the entry on the seventh day records that both eyes were "clean". Dr Paine remembers that the significant improvement was within two or three days in the three babies who responded to treatment.

If penicillin is to be given credit for the cure, the three-month gap between the first and second entry in the case notes has to be considered to make sure there is no alternative explanation. Mr Nutt's female ward case notes of 1930 indicate consistently when his patients were discharged from the ward, so it can be inferred that the baby Peter had one unbroken stay in hospital arising from the initial diagnosis. It is also clear that it was quite feasible in the early 1930 s for the infection in a case of gonococcal ophthalmia still to be active three months after the diagnosis was made, even when treatment was given in hospital. ${ }^{13}$ The treatment given to this baby in the early months was not very effective by modern standards. It has been shown in a retrospective study ${ }^{14}$ dealing with such pre-penicillin days that silver nitrate did not suppress the development of gonococcal ophthalmia neonatorum any more successfully than other drops. The other treatment that was prescribed would not be curative.

The writers of the case notes of figs. 2 and 3 have not been identified with certainty. The distinctive handwriting of the penicillin sections of both cases is neither that of Mr Nutt ${ }^{15}$ nor of Dr Paine, and indeed the misspelling "pinicillin" is what one would expect from a writer unfamiliar with Fleming's recent publication on penicillin. It seems superfluous to discuss whether "pinicillin" as recorded here, is the same thing as penicillin.

The other case (fig.3) can be described more briefly. It concerns a girl, Sheila, six days old when admitted on 2 December 1930 with a diagnosis of "ophthalmia

${ }^{13}$ S. M. Laird, 1984, personal communication.

14 [Anon.], 'Prophylaxis of ophthalmia neonatorum', Lancet, 1949, i: 313-314.

${ }^{15}$ U. S. Clarke, 1984, personal communication. 
C. G. Paine and penicillin therapy

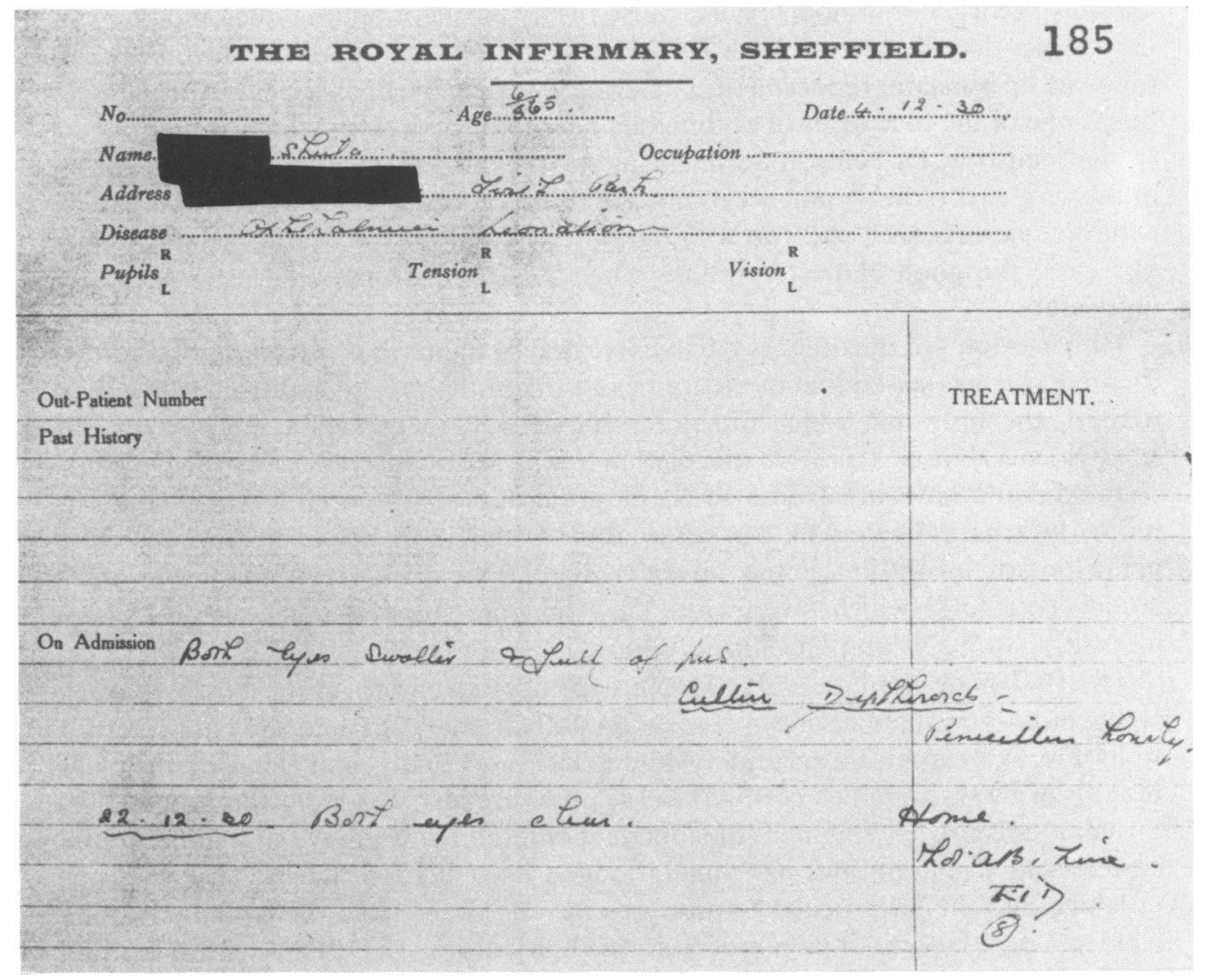

Figure 3. Case notes of 1930 recording penicillin therapy. Source: as for fig. 2 .

neonatorum", the eyes being "full of pus" and the culture growing "diphtheroids". The total entry is as follows under the admission date of 4 December 1930.

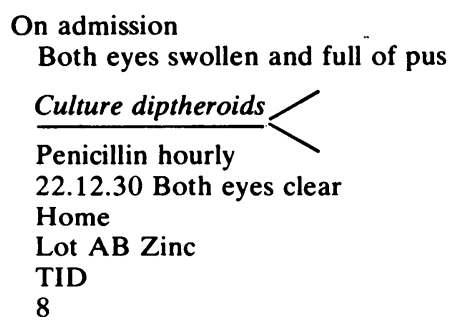

Here, the information is clearly stated that penicillin was given hourly and that treatment was effective enough to allow the baby to be sent home eighteen days later with clear eyes. It is, of course, unsatisfactory to have been left with diphtheroids as 
the only recorded, but improbable, cause of the purulent ophthalmia, and one can only regret that the two ink lines visible in fig. 3 after "diphtheroids" have not been followed up by a later report on the bacteriology which the lines appear to promise. If this is one of the four cases of opthhalmia neonatorum that have been remembered so confidently by $\mathrm{Dr}$ Paine, it would mean that the ultimate bacteriological diagnosis in this case was either gonococcal or staphylococcal, since he described two babies with the one organism and two with the other. Whatever the causative infection in this case, the good clinical response when penicillin drops were used is clearly illustrated.

The case notes of the other two babies treated by Paine and Nutt are unlikely to be found. Paine has stated that of the four cases of ophthalmia neonatorum which they treated, the only one which did not respond well to penicillin was one of the staphylococcal cases. It is mere speculation to wonder whether the case which did not respond could have involved a resistant strain of staphylococcus, which would in those days have been rare. An alternative explanation would be less effective penicillin administration. Paine, however, regularly used his own method to assay crude penicillin, ${ }^{16}$ which favours the view that the staphylococci were relatively insensitive to his weak penicillin solutions.

The 1930 male ward journal of Mr Nutt was not so well kept as the female journal, so the most important adult eye case successfully treated by Paine and Nutt referred to by Florey ${ }^{17}$ cannot be accurately dated. The most likely date is during the early months of 1931, for which period the case notes are lost. The story was repeated by Dr Paine recently. A fragment of stone had entered the right eye of a miner at the corneo-scleral margin and had finally lodged itself behind the iris. The eye was inflamed and the intra-ocular tension was raised. Swabs from the conjunctival sac yielded a pure culture of pneumococci, which, according to Dr Paine, was regarded as of ominous significance. After irrigation with penicillin for forty-eight hours, the conjuctiva appeared clear and a second swab proved sterile. The stone was then removed and the patient recovered $6 / 6$ vision in the affected eye. ${ }^{17}$

Paine also worked with Dr A. Rupert Hallam, Dermatologist at the Infirmary, in treating three cases of sycosis barbae by means of the crude filtrate of the culture medium applied topically to the beard area. They were unsuccessful in all three. No patients' records covering the time of these unsuccessful skin trials have survived, so the details of management are not known. These could be of interest, because Hallam is known to have favoured the use of surgical spirit as a cleansing agent and as a dressing in his management of sycosis barbae.$^{18}$ Spirit could have inactivated what penicillin was present, due to the presence of heavy metals as contaminants and the effect of spirit on them. ${ }^{19}$ Perhaps the concentration of penicillin was too low to be clinically effective.

It is often difficult to assign a historical order to discoveries, but it would seem that the clinical records reproduced above are the earliest published recorded cures

${ }^{16} \mathrm{C}$. G. Paine, 1984, personal communication.

${ }^{17}$ Florey et al., op. cit., note 5 above, p.634.

${ }^{18} \mathrm{R}$. Hallam, 'Recurrent boils', Br. med. J., 1932, ii: 670-672.

${ }^{19} \mathrm{R}$. Sutherland, 1984 , personal communication. 


\section{G. Paine and penicillin therapy}

using penicillin where the evidence has been substantiated by case notes. To take one example in history where the evidence is inadequate, Lister is said to have used culture filtrates of Penicillium glaucum in 1877 with some clinical success in treating infected wounds and abscesses. ${ }^{20}$ However, he left no satisfactory documentation to assist the scientific assessment of his work. Such references to the antibacterial effects of $P$. glaucum are now viewed with caution, since this term was used indiscriminately in the late nineteenth century to describe any green Penicillium species. ${ }^{21} \mathrm{~A}$ number of species of this genus produce penicillin, but they can also produce toxic products or antibiotics of limited therapeutic value. ${ }^{22}$

The records presented here establish some facts and help to correct errors which have crept into the previously published histories of penicillin. It is now clear that Paine's contribution was made when he was at the Sheffield Royal Infirmary and not, as has been stated ${ }^{10}$ at the Jessop Hospital for Women. There is no evidence here that his patients were treated as late as 1932 as has been stated, ${ }^{23.24}$ a suggestion that Paine has consistently denied. It is possible that the date of 1932 given by Macfarlane and others for Paine's early work on penicillin therapy has gained credibility through an assumed working link with Florey, who took up his new appointment to the Chair of Pathology in Sheffield in 1932. Our discovery of authoritative dates also corrects statements such as those made by Macfarlane ${ }^{23}$ when he wrote, "Curiously enough, attempts to use penicillin were being made in 1932, not in Fleming's laboratory, but in Florey's Department at Sheffield". Professor J. Sholto Douglas was, in fact, the Professor of Pathology in Sheffield at the time of Paine's work. The claim of Baldry that "whilst working at the Royal Infirmary in Sheffield he [Florey] had watched with interest C.G. Paine, a former pupil of Fleming, applying crude penicillin containing culture filtrates to wounds" ${ }^{25}$ is no more than imaginative writing. After Florey had taken up his appointment in Sheffield, Paine told him about the work which he had finished a year or more previously. According to Paine, Florey at that time took no obvious notice. Bickel, one of Florey's biographers, says that this verbal communication about penicillin took place during Florey's last few months in Sheffield, ${ }^{26}$ which would have made it just prior to 1 May 1935. Dr Paine is emphatic, however, that he told Florey about his penicillin work at a much earlier date probably in 1932, shortly after Florey had taken up the Joseph Hunter Chair of Pathology at Sheffield in March of that year. ${ }^{27}$

Why did Paine not continue with his promising, and in some cases dramatically successful work? First, and most importantly, it would seem that the move in 1931 to the annexe of the Jessop Hospital for Women distracted him. By then, his main interest was in puerperal fever, and at Norton Annexe he was to become fully committed to work on the aetiology of that disease, culminating in a number of publications on the subject. His MD thesis submitted in 1932 was entitled 'A study of

\footnotetext{
${ }^{20} \mathrm{~W}$. Fraser-Moodie, 'Struggle against infection', Proc. $R$. Soc. Med., 1971, 64: 87-94.

${ }^{21}$ J. I. Pitt, The genus Penicillium, New York, Academic Press, 1979, pp.4-5.

${ }^{22}$ Florey et al., op. cit., note 5 above, vol. 1, pp.230-237.

${ }^{23}$ R. G. Macfarlane, Howard Florey, Oxford University Press, 1979, p.219.

${ }^{24}$ H. D. Riley jun., 'The story of penicillin', J. Okla. State Med. Assoc. 1972, 65: 107-119.

${ }^{25} \mathrm{P}$. Baldry, The battle against bacteria, Cambridge University Press, 1976, p.106.

${ }^{28}$ L. Bickel, Rise up to life, London, Angus \& Robertson, 1972, p.45.

${ }^{27}$ Chapman, op. cit., note 8 above, p. 45 .
} 


\section{Wainwright and H. T. Swan}

immunity to haemolytic streptococci in puerperal infection'. Paine has also stated that like Fleming, he had found crude penicillin to be tantalizingly variable. American work ${ }^{28}$ later confirmed his observations that cultures of $P$. notatum tend to lose spontaneously their ability to form penicillin, either entirely or partially. Similarly, maximum concentrations of penicillin created by the mould frequently persist for only a brief period and then drop off sharply. Crude penicillin filtrates were also found to deteriorate rapidly on storage, and Paine, like Fleming, had no technique of preserving them.

Paine has stated clearly that his work was not initiated by Fleming, nor, remembering his undergraduate days, had he ever seen Fleming use penicillin as an antiseptic. He did, however, let Fleming know subsequently that the mould was losing its potency.

Incredible as it seems now, considering his initial successes, Paine never published in the scientific literature anything about his clinical work on crude penicillin. Indeed, his work would probably never have come to light had not Howard Florey told Masters about it and then mentioned it in the second volume of Antibiotics. ${ }^{5}$ On the other hand, it is possible that an important journal would not have published a paper based on the limited evidence which Paine had accumulated.

\section{RELATIVE LACK OF INTEREST IN PENICILLIN}

An alternative to the writing of a formal paper would have been for Paine or his associates to have presented their findings at scientific meetings. Nutt, for example, was in the habit of speaking at meetings of the North of England Ophthalmological Society, which were sometimes held in Sheffield. However, he made no mention of penicillin in communications to this society when it met at Manchester, Sheffield, and Leeds during January 1931, nor again in Sheffield in March 1931 and April 1932, ${ }^{29}$ the dates most likely to be relevant to the penicillin work. In one communication given just before that period, the names of Nutt and Paine appear together, ${ }^{30}$ so a precedent was set but unfortunately not followed when it came to the penicillin work itself. Nutt may well have felt little excitement at the time about Paine's penicillin work; and even Paine's own sister was unaware of her brother's contribution, although she was a medical student in Sheffield during the early 'thirties. ${ }^{31}$

Hallam also presented clinical reports to meetings of the British Medical Association and the North of England Dermatological Society. A meeting of the latter society was held in Sheffield on 13 March $1931,{ }^{32}$ but again there was no mentioned made of penicillin and of the three cases treated with it.

A communication to the British Medical Association in July $1932^{18}$ gave Hallam a perfect opportunity to mention the penicillin work, even if only from the viewpoint of a therapeutic failure. His paper was devoted to studies on recurrent boils caused by $S$. aureus. In it, he suggested that effective treatment should involve frequent cleansing

${ }^{28} \mathrm{~J}$.W. Foster, H.B. Woodruff, and L.E. McDaniel, 'Microbiological aspects of penicillian', J. Bact., 1943, 46: 421-433.

${ }^{29}$ Trans. Ophthalmol. Soc. UK., 1931, 51: 584; 1932, 52: 556.

${ }^{30}$ A. B. Nutt, 'Reduplication of the internal canthus', ibid., 1930, 50: 614-615.

${ }^{31}$ U. S. Clarke, 1984, personal communication.

${ }^{32}$ R. Hallam, 'Clinical meeting of the North of England Dermatological Society', Br. J. Derm., 1931, 43: 304-306. 


\section{G. Paine and penicillin therapy}

with spirit and the application of gauze soaked in spirit. Although Hallam mentioned nothing about penicillin in this paper, he commented upon the view of Brocq that boils can be cured by the application of fresh yeast, stating that "the yeast he [Brocq] employed may be different to the variety used by brewers in this country; certainly an extensive trial of the latter convinced me that it is useless for their purpose". So, although Hallam was amenable to the possibility of curing bacterial infections with yeast, he appears not to have seen anything in Paine's work to interest him. Dr Paine is confident that Hallam was aware of his work with Nutt, where he had used penicillin on eye infections.

Even if Paine or his collaborators had published something about their penicillin work it is open to doubt whether this would have had an impact on the scientific community during the early $1930 \mathrm{~s}$. After all, top medical scientists at the time, including Colebrook and Florey, also knew about Fleming's work. Florey had been an editor of the British Journal of Experimental Pathology, which published Fleming's first paper on penicillin; and later, in 1932, he heard of penicillin from Paine himself. He is also likely to have been reminded about penicillin when he attended a meeting of the Pathological Society of Great Britain in the same year at Oxford, where Fleming read a paper on penicillin. ${ }^{33}$ A group photograph taken at that meeting shows Florey and Fleming standing next to each other, though this need not have significance. ${ }^{34}$

It is important also to judge history with a knowledge of contemporary thinking. In 1930, while there were antiseptics for local use, there was nothing which could be given by injection against the common infections, although syphilis had been treated for some time by injection of arsenicals. Treatment by mouth consisted of herbs and extracts, which, of course, included quinine, but not by disease-specific chemicals. Prontosil was not introduced as an antibacterial agent until 1935, and its successor sulphapyridine, known as M \& B 693, revolutionized therapeutics and medical thinking in 1938. It was with minds prepared by the sulphonamides and possessing a greater knowledge of advanced techniques that the Oxford workers made their brilliant progress. Fleming and Paine had no such advantage in 1928 and 1930.

Paine has stated emphatically ${ }^{35}$ that Fleming was well aware of the potential of penicillin for wider clinical use than merely as an antiseptic. This view, which was recently expressed by another of Fleming's former students ${ }^{36}$ has not been clearly supported by Fleming's own publications, though his historic paper of 1929 contains the following words, which seem to show that he had an important awareness which was in advance of contemporary therapeutics: "It is suggested that it [penicillin] may be an efficient antiseptic for application to, or injection ${ }^{37}$ into, areas infected with penicillin-sensitive microbes". This is not an early vision of systemic therapy with penicillin, but a practicable next step in the study and development of a remarkable preparation. Chain, amongst others, has pointed out that Fleming could easily have

\footnotetext{
${ }^{33}$ A. Fleming, 'Two selective culture media', Proc. Pathol. Soc. Gt Britain, see J. Path. Bact.., 1932, 35: 649-651.

${ }^{34}$ Ibid., 1932, 35: plate XC11.

${ }^{35} \mathrm{C}$. G. Paine, 1984, personal communication.

${ }^{36} \mathrm{G}$. C. Haslam, 'Fleming and the development of penicillin', letter, Sunday Telegraph, 8 April 1984.

${ }^{37}$ Our italics.
} 
demonstrated the systemic therapeutic potential of penicillin by injecting the crude filtrate into previously infected mice. Chain's view is that Fleming just did not think of this experiment. ${ }^{38}$

\title{
SOME EARLY WORK OF FLEMING AND OTHERS USING PENICILLIN
}

It is on record that Fleming used penicillin on 9 January 1929, when he treated the chronically infected nasal antrum of Dr S. R. Craddock. ${ }^{39}$ This has generally been claimed to be the first occasion that penicillin was ever used clinically, even though it was ineffective. The following month, Fleming gave a laboratory-based talk on his penicillin work to the Medical Research Club on 13 February 1929. This was entitled 'A medium for the isolation of Pfeiffer's Bacillus'. This paper was received without enthusiasm ${ }^{40}$ and appears never to have been published. Fleming's first reported successful clinical use of penicillin may not antedate 1932, when he cured Dr K. B. Rogers $^{41}$ of pneumococcal conjunctivitis, but there must have been earlier cases without surviving documentation, as are illustrated by his own comments below.

Two small references to Fleming's early work on the therapeutic value of local penicillin treatment appear to have been overlooked. Fleming himself made a reference to his clinical attempts to use penicillin or what is assumed to be penicillin, when he was commenting on a paper on antivirus, which had been read on behalf of Professor Besredka at a meeting of the Royal Society of Medicine on 15 May $1929 .{ }^{42}$ He stated:

\begin{abstract}
I found that when a particular mould had been grown in broth for a week or ten days, the filtrate of the culture had remarkable inhibitory properties on the growth of some microbes, especially the pyogenic cocci. This filtrate, like Besredka's antivirus, consists of nutrient broth, except that instead of being exhausted by a bacterium, it has supported the growth of a mould for some time (not to exhaustion). I have applied this filtrate to a number of septic wounds (abscesses, burns, ulcers, etc.), and so far the results are certainly not inferior to the cases cited by Besredka. One patient treated during the last ten days is interesting. A woman had indolent ulcers in various parts of the body. These ulcers had existed for over two months and showed little sign of healing. The infecting agents in each case were staphylococci and streptococci. The filtrate was applied in compresses every four hours and in three or four days the aspect of the ulcers completely changed, they became healthy looking, granulations formed and healing commenced and is progressing rapidly.
\end{abstract}

The treatment of this case of indolent ulcers would have begun around 5 May 1929 , but further description and documentation of the case does not seem ever to have been attempted. It would be unreasonable to doubt that Fleming was referring to the successful use of penicillin when he spoke of using "a particular mould", but his case of the woman with the indolent ulcers has remained unsatisfactory in its lack of further documentation. Nevertheless, this comment in the course of a discussion would seem to be the first published utterance by Fleming on the use of penicillin as a therapy, and came only five days after his historic paper had been received for publication by the British Journal of Experimental Pathology.

${ }^{38}$ E. Chain, 'Penicillin - the crucial experiment', Chemtech., 1980, 10: 474-481.

${ }^{39}$ R. G. Macfarlane, Alexander Fleming, London, Chatto \& Windus, 1984, p.129 ref.

${ }^{40}$ Ibid., p. 130.

${ }^{4} \mathrm{R}$. Hare, 'New light on the history of penicillin', Med. Hist., 1982, 26: 1-24, see p.19.

${ }^{42}$ A. Besredka, 'Antivirus therapy in infectious diseases', Proc. R. Soc. Med., 1929, 22: 1579-1598, see pp.1596-1597. 


\section{G. Paine and penicillin therapy}

Another reference which appears to have been overlooked concerning early clinical trials of penicillin is a comment made in 1954 by the former Assistant Director of the Surgical Unit at St Mary's Hospital, Mr Arthur Dickson Wright. He seems to have been involved in some of the therapeutic trials along with Fleming, but published no work on the subject. He frequently spoke during discussion time after lectures and made the following statement after Fleming had read a paper at a meeting of the Medical Society of London on 12 February 1945:43 "I was interested in penicillin because in 1928 Professor Fleming gave me some to use on cases. It was a yellow fluid in a big test tube, a filtered medium from penicillin cultures and seemed to work satisfactorily."

It is possible that Dickson Wright was involved in the same early clinical work referred to by Fleming when speaking at the Royal Society of Medicine, because Dickson Wright not only worked in the same hospital but held the treatment of indolent and varicose ulcers as one of his interests at that time. He made no mention of penicillin, however, in any of the papers dealing with his special interest, including one he gave on the treatment of indolent ulcer of the leg, delivered to the Medical Society of London on 23 February $1931 .{ }^{44}$

Interestingly, the published discussion which took place at the end of that paper included a cross-reference to his involvement with Fleming, for Sir Almroth Wright referred to collaboration between Fleming and Dickson Wright - but still there was no mention of penicillin. One can only surmise that any collaborative efforts of Fleming and Dickson Wright were largely unsuccessful, or insufficiently appreciated at the time, despite early enthusiastic comments and later reminiscences. It can also be noted that Dr Paine says he knew nothing of Dickson Wright's involvement with penicillin. We have not found any other reference to Fleming's clinical work on the patient with the indolent ulcers, nor evidence that Dickson Wright was working with him on that case. Investigation of case notes around 1929, which may still exist in St Mary's Hospital, could prove interesting if they have not already been fully explored. For the moment at least, the Paine-Nutt clinical notes provide the most satisfactory and perhaps the only contemporarily documented evidence to show that clinical success with penicillin was achieved prior to the work of Florey and Chain.

Is it then likely that the Paine-Nutt patients were the first to benefit from penicillin cures? So long after the event, we are now dependent on surviving records, and such written reports must be carefully assessed. Fleming's reference to the use of penicillin in the indolent ulcer case (see above) is the only published statement we have discovered which indicates that he had clinical success before Paine. However, the presentation of the evidence on that occasion, despite its great interest now, was only anecdotal and was made during discussion time after he had listened to a paper on another subject. The next reference to successful therapy concerned the eye infection of Dr Rogers, and this was recorded in a manuscript source dealing with 1932. This post-dates Paine's cases. Thus, if we are going to make our deductions solely from records which are historically and scientifically satisfactory, Paine's cases could be regarded as the first clinical successes. But we have Fleming's own remarks

${ }^{43}$ A. Fleming, 'The use and limitations of penicillin', Trans. Med. Soc. Lond., 1945, 64: 142-149.

${ }^{44} \mathrm{~A}$. Dickson Wright, 'The treatment of indolent ulcer of the leg', ibid., 1931, 53: 237-251. 


\section{Wainwright and H. T. Swan}

to suggest that there may have been others which were never recorded or where the records have yet to be discovered.

\section{LATER USE OF CRUDE PENICILLIN FILTRATES}

Some idea of what Fleming or Paine might have achieved in the clinical field in the 1930s had they continued working with penicillin can be gained by considering work done using the crude mould juice during the early 1940s. By that time, purified penicillin was still not generally available, so number of workers examined the curative properties of the crude filtrates. In 1943, for example, Robinson and Wallace, ${ }^{45}$ working at the Allegheny General Hospital in Pittsburgh, tested the clinical effectiveness of dressings which were inoculated with $P$. notatum or soaked in crude broths, and claimed success against a wide range of infections. During the same year, Professor J. V. Duhigg and Dr David Grey cured a woman dying of septicaemia, using a series of injections of crude penicillin. ${ }^{46}$ Hobson and Galloway also reported clinical successes in a paper entitled 'Home-made penicillin'. ${ }^{47}$ They concluded that, even at their poorest, penicillin-soaked dressings proved immensely superior to anything with which they had been previously acquainted. But perhaps the most interesting use of crude penicillin, in relation to Paine's work, was published as a letter by M. A. Cooke while working at Bradford Royal Infirmary. ${ }^{48} \mathrm{He}$ showed that the crude extract could cure sycosis barbae, the disease against which Paine and Hallam had had no success. When he used daily sprays over a six-week period, six cases of the infection were cured, another six were cured after initial relapses, and two other cases showed improvement; and there were no failures. A year earlier, Taylor and Hughes ${ }^{49}$ also reported improvements in patients suffering from sycosis barbae following application of crude penicillin and also noted the appearance of penicillin-insensitive bacteria. It should be remembered that these workers had the marked advantage over both Fleming and Paine in that they knew that penicillin was an effective agent before they began their work.

\section{PAINE'S WORK IN THE PERSPECTIVE OF LATER EVENTS}

A recent anonymous review in the Lancet of Macfarlane's book on Fleming ${ }^{50}$ states: "We are still not clear exactly how Florey decided that penicillin was a likely winner". There seems little doubt that Florey knew of Fleming's penicillin work from the outset. Like other eminent scientists at that time, being abreast of the scientific literature, he seems to have regarded penicillin merely as an interesting phenomenon, subsequently to be remembered. In 1932, Paine told Florey about the clinical cures which had been achieved, and Florey could hardly have been unaware that Fleming was using penicillin in selective culture media. From Chain's reminiscences $^{51}$ we know that Florey was familiar with Raistrick's insufficiently

${ }^{45} \mathrm{G}$. H. Robinson and J. E. Wallace, 'An inoculated penicillin dressing', Science, 1943, 98: 329-330.

${ }^{46}$ Bickel, op. cit., note 26 above, pp.229-230.

${ }^{47}$ A. J. Hobson and L. D. Galloway, 'Home-made penicillin', Lancet, 1944, i: 230-231.

${ }^{48} \mathrm{M}$. A. Cooke, 'Penicillin in sycosis barbae', ibid., 1945 i: 543-544.

${ }^{49}$ P. H. Taylor and K. E. A. Hughes, 'Infective dermatoses treated with penicillin', ibid., 1944, ii: 780-784

${ }^{50}$ Anon. 'Penicillin: If only', ibid., 1984, i: 154-155.

${ }^{51}$ T. I. Williams, Howard Florey, Oxford University Press, 1984, p.90. 


\title{
C. G. Paine and penicillin therapy
}

successful attempts to purify penicillin in $1933 .{ }^{52}$ In 1938 , when Chain began his own search of the literature concerning microbial antagonism, he eventually concentrated his attention on a few particularly interesting examples of this phenomenon, only one of which was penicillin. It seems that Chain was initially much attracted by gramicidin, but on discussing the matter, Florey insisted that penicillin should have priority. ${ }^{53}$ Was this discussion in any way influenced by Paine's work? Bickel seems to think that it was. ${ }^{54}$ Florey, however, told Masters that Paine's work had not influenced him and that he remembered it only when questioned by Masters some time in the early 1940 s. In a recent letter, Lady Florey kindly offered some comments on this very question:

\begin{abstract}
I did not know Dr Paine as I was Lord Florey's second wife, but my husband always spoke warmly of him, as indeed he did of Sheffield people and of the time he spent there.... My husband moved from Cambridge to Sheffield in March 1932 and Dr Paine's work with penicillin is generally referred to as starting in 1932, so communications seem likely to have been by word of mouth. My husband certainly knew about and remembered Dr Paine's work and mentioned it as part of the early history of penicillin, for example in the book Antibiotics.
\end{abstract}

The Oxford group acknowledged the use of Paine's technique for testing the leucotoxicity of substances, ${ }^{55}$ modifying the method only slightly for their own use when demonstrating that purified penicillin was harmless to the white cells of the blood. Their acknowledgement is further evidence that Paine's name will have reappeared at that time.

At the end of our interview Dr Paine was asked where he placed himself in the penicillin story. He replied:

Nowhere - a poor fool who didn't see the obvious when it was stuck in front of him. I suppose that there are many things that conspired to stop me doing it. I'm sorry, but there it is. It might have come on to the world a little earlier if I'd had any luck.

Paine had obviously seen a therapeutic potential in penicillin, although mainly in relation to its use as an antiseptic, but he was beaten by the unstable nature and variability of the crude extract. It took almost another ten years before a biochemist like Chain could confidently state that purification of penicillin could be done "rapidly and easily". ${ }^{56}$ Today it may seem difficult to understand how both Fleming and Paine, having seen some clinical successes following the use of penicillin, should fail to have moved mountains to promote its development, but we have the benefit of hindsight and know the enormous changes in medicine wrought by penicillin. Antibiotics were not "in the air" in the early 1930s and thinking was more devoted to antiseptics. Fortunately, the pioneering efforts of Fleming, Paine, and others involved in early penicillin therapy when it was used locally, with variable success, were eventually brought to fruition by the drive of Florey and Chain and the other members of the Oxford team who, by purifying and testing penicillin, gave the world the first effective injectable antibiotic.

\footnotetext{
${ }^{52}$ Hare, op. cit., note 41 above, p.10.

${ }^{53}$ Williams, op. cit., note 51 above.

${ }^{54}$ Bickel, op. cit., note 26 above, p.87.

${ }^{55}$ Abraham et al., op. cit., note 2 above, p. 182.

${ }^{56}$ Chain, op. cit., note 38 above.
} 


\section{Wainwright and H. T. Swan}

\section{ACKNOWLEDGEMENTS}

Figures 2 and 3 are reproduced by permission of the Controller of Her Majesty's Stationery Office from a volume of case notes deposited in South Yorkshire County Records Office, and with the permission of $\mathrm{Mr}$ Nutts's heir. Thanks are particularly due to Dr C. G. Paine for his agreeing to an interview with MW and for subsequent correspondence. We are also grateful to Lady Florey for her letter; to Dr U. S. Clarke, Mr Nutt's sister, for her special help; to Dr S. M. Laird, Mr G. R. Weeks, and Mr Ian Strachan for their specialist contributions, and finally to Mrs C. Short, South Yorkshire Archivist for her co-operation. 